\title{
Lipid Peroxidation and Antioxidant Levels, and Alpha Naphthyl Acetate Esterase Activity of Peripheral Blood Lymphocytes in Mallard, Muscovy and Pekin Ducks
}

\author{
T. KARACA ${ }^{1}$, M. CEMEK ${ }^{2}$, M. KANTER ${ }^{3}$ \\ ${ }^{1}$ Department of Histology-Embryology, Veterinary Medicine, \\ Yüzüncü Yil University, Van, Turkey \\ ${ }^{2}$ Department of Chemistry (Biochemistry Division), Faculty of Science, \\ Afyon Kocatepe University, Afyon, Turkey \\ ${ }^{3}$ Department of Histology-Embryology, Faculty of Medicine, \\ Trakya University, Edirne, Turkey \\ Received June 24, 2003 \\ Accepted November 10, 2005
}

\begin{abstract}
T. Karaca, Cemek M., Kanter M.: Lipid Peroxidation and Antioxidant Levels, and Alpha Naphthyl Acetate Esterase Activity of Peripheral Blood Lymphocytes in Mallard, Muscovy and Pekin Ducks. Acta Vet. Brno 2006, 75: 33-38.

The aim of this study was to determine blood levels of malondialdehyde (MDA), reduced glutathione (GSH), ceruloplasmin and vitamin $\mathrm{C}$, and the percentages of peripheral blood Tlymphocytes using the alpha-naphthyl acetate esterase (ANAE) method on Mallard (Anas platyrhynchos), Muscovy (Cairina moschata) and Pekin (Anas domestica) ducks. Blood samples were obtained from 8 adult ducks of each breed. The serum levels observed in Mallard, Muscovy and Pekin ducks respectively were 0.8, 1.07 and $1.3 \mathrm{nmol}$ MDA per $\mathrm{ml} ; 77.4,66.9$ and $78.7 \mathrm{mg}$ GSH per $100 \mathrm{ml} ; 23.9,26.1$ and $24.1 \mathrm{mg}$ ceruloplasmin per $100 \mathrm{ml}$; and $0.50,0.52$ and $0.70 \mathrm{mg}$ vitamin C per $100 \mathrm{ml}$. The percentage of the ANAE (+) lymphocytes was $57.9 \%, 54.8 \%$ and $55.1 \%$ in Mallard, Muscovy and Pekin ducks, respectively. In this study, blood levels of lipid peroxidation and nonenzymatic antioxidants in the Mallard, Muscovy and Pekin ducks were determined.
\end{abstract}

Lipid peroxidation, antioxidant, alpha-naphthyl acetate esterase, T-lymphocyte, duck

Reduced glutathione (GSH), L- $\gamma$-glutamyl-L-cysteinyl-glycine, is a ubiquitous tripeptide produced by plants and animals alike from the amino acids glutamine, glycine and cysteine. Its sulphur-hydrogen (thiol) group is a potent reducing agent, and GSH can be considered one of the body's most important water-soluble antioxidants (Hudson 2001). GSH provides powerful antioxidant protection to body systems heavily exposed to reactive oxygen species, such as the lung (Kelly 1999; Rahman and MacNee 1999). Another property of reduced glutathione is to regulate inflammation and the immune response (Piertarinen-Runtti et al. 2000).

Malondialdehyde (MDA) is one of the aldehydic end products of the lipid peroxidation cascade (Esterbauer and Cheeseman 1990).

Ceruloplasmin, a blue copper glycoprotein with ferroxidase and oxidase activities, is an important serum antioxidant (Akkus 1995); as an acute phase protein, it exhibits a moderate response in humans (Min et al. 1991) and chickens (Koh et al. 1996). Vitamin $\mathrm{C}$ (ascorbic acid) is a water-soluble vitamin, with antioxidant properties. Vitamin $\mathrm{C}$ has been found to be most effective in protecting plasma lipids from oxidative damage (Henson et al. 1991).

Non-specific esterase is widely distributed in various types of cells. Cytochemical esterase activity is commonly used to differentiate types of leukocytes and leukaemia cells (In oue

Phone: +904322251024

Fax: +90 4322251127

E-mail: turankaraca74@hotmail.com turan.karaca@gmail.com 
et al. 1991). Alpha-naphthyl acetate esterase is a non-specific esterase. The pattern of esterase activity revealed by this method provides a discriminating marker for mature Tlymphocytes showing dense, localized, dot-like positive responses.

Mueller et al. (1975) showed in the mouse, Kajikawa et al. (1983) in cattle, Higgy et al. (1977) and Knowles and Halper (1980) in humans and Maiti et al. (1990) in chickens that the percentage of ANAE $(+)$ peripheral blood lymphocytes accurately reflects the percentage of mature T-lymphocytes forming E-rosettes with sheep erythrocytes (SRBC) and separations of B lymphocytes by the erythrocyte antibody complement rosette method (EAC rosette method) (Fudenberg et al. 1978).

The percentage of peripheral blood T-lymphocytes has been found to be approximately $56 \%$ (Maiti et al. 1990) or 56.4\% in chickens (A sti et al. 1999), 82.3\% in dogs (Asti et al. 1993), 83\% in Van cats (Yörük et al. 1998), 85\% in humans (Müller et al. 1981) and $64.2 \%$ in cows (Yang et al. 1979) using an ANAE staining procedure. Some researchers suggest that ANAE enzyme is a lysosomal enzyme (Zicca et al. 1981; Miyasaka et al. 1983).

Pruthi et al. (1987), Maiti et al. (1990) and Asti et al. (1999) reported that Tlymphocytes from the peripheral blood lymphocytes of chickens display ANAE staining. However, the present study is the first to determine peripheral blood lymphocytes of ducks using the ANAE method.

The aim of this study was to determine levels of blood lipid peroxidation and antioxidant and peripheral blood T-lymphocyte percentages in Mallard (Anas platyrhynchos), Muscovy (Cairina moschata), and Pekin (Anas domestica) ducks.

\section{Materials and Methods}

A total of 24 healthy adult ducks (body weight: Mallard 2.0 - $2.5 \mathrm{~kg}$; Muscovy 3.8 - $4.7 \mathrm{~kg}$; Pekin ducks 3.2 $4.3 \mathrm{~kg}$; each breed represented by 8 birds) were kept in animal houses with free access to open-air water surface (8 animals in each room). Ducks (50:50 males and females) were purchased from a local farm in the Van area. These ducks were about 10-12 months old, reared under natural conditions, and living on duck food. They had free access to food (containing $23 \%$ protein and $3100 \mathrm{kcal} \cdot \mathrm{kg}^{-1} \mathrm{ME}$ ); Vangölü Food Factory, Van, Turkey) and water.

Blood samples for biochemical analysis were taken from the vena ulnaris. The levels of malondialdehyde (MDA), reduced glutathione $(\mathrm{GSH})$, ceruloplasmin and vitamin $\mathrm{C}$ in blood were determined. Blood malondialdehyde (MDA) concentration was determined using the method described by Jain et al. (1989) and based on thiobarbituric acid (TBA) reactivity. Briefly, $0.2 \mathrm{ml}$ of erythrocyte packets, $0.8 \mathrm{ml}$ of phosphate buffer ( $\mathrm{pH} 7.4)$, $0.025 \mathrm{ml}$ of butylated hydroxytoluene (BHT) and $0.5 \mathrm{ml}$ of $30 \%$ trichloroacetic acid (TCA) were added to tubes and mixed. After incubating for $2 \mathrm{~h}$ at $-20^{\circ} \mathrm{C}$, the mixture was centrifuged $(400 \mathrm{~g})$ for $15 \mathrm{~min}$. Then $1 \mathrm{ml}$ of supernatant was added into each tube, and $0.075 \mathrm{ml}$ of $0.1 \mathrm{~m}$ EDTA and $0.25 \mathrm{ml}$ of $1 \%$ TBA were added. These tubes with teflon-lined screw caps were incubated at $90{ }^{\circ} \mathrm{C}$ in a water bath for $15 \mathrm{~min}$ and cooled to room temperature. Optical density was measured at 532-600 $\mathrm{nm}$ in a spectrophotometer (Novaspec II PharmaciaBiotech, Biochrom Ltd., UK).

Blood GSH concentration was measured using the method described by Buetler et al. (1963). Briefly, 200 $\mu 1$ of whole blood were added to $1.8 \mathrm{ml}$ of distilled water. Three millilitres of precipitating solution were mixed with haemolysate. The mixture was allowed to stand for approximately $5 \mathrm{~min}$ and then filtered. Two millilitres of filtrate were taken and added to another tube, and then $8 \mathrm{ml}$ of phosphate solution and $1 \mathrm{ml}$ of DTNB [5,5'dithiobis- (2-nitrobenzoic acid)] were added. A blank was prepared with $8 \mathrm{ml}$ of phosphate solution, $2 \mathrm{ml}$ of diluted precipitating solution (three to two parts of distilled water), and $1 \mathrm{ml}$ of the DTNB reagent. A standard solution of the gluthathione was prepared $\left(40 \mathrm{mg} \cdot 100 \mathrm{ml}^{-1}\right)$. Optical density was measured at $412 \mathrm{~nm}$ in the spectrophotometer.

Serum ceruloplasmin activity was determined using the Altered Ravin Method (Yenson 1993). Five ml phenylendiamine substrates were added to two tubes (curve and test). Then, $1 \mathrm{ml}$ sodium azide solution was added to the curve tube only. After this, $0.1 \mathrm{ml}$ serum was added to both the curve tube and the test tube, and the contents were mixed. Both mixtures were kept at $37^{\circ} \mathrm{C}$ for $15 \mathrm{~min}$. Finally, $1 \mathrm{ml}$ sodium azide solution was added only to the test tube. After $15 \mathrm{~min}$, optical density was measured at $546 \mathrm{~nm}$ in the spectrophotometer.

Serum vitamin C level was determined after derivatization with 2,4-dinitrophenylhydrazine (Omaye et al. 1979). 
Heparinized blood samples were taken from 8 healthy adult Mallard, Muscovy, and Pekin ducks for ANAE staining for the purpose of this study. For ANAE demonstration (Maiti et al. 1990), air-dried blood smears were fixed in glutaraldehyde-acetone mixture for 3 minutes at $-10{ }^{\circ} \mathrm{C}$. Following fixation, the smears were rinsed in distilled water and then allowed to dry at room temperature for 30 minutes. Blood smears were incubated ( $\mathrm{pH} 6.8)$ for 4 hours, and after incubation the preparations were washed in distilled water and counterstained with $1 \%$ methyl green for 30 minutes. Following dehydration in increasing concentrations of ethanol, the preparations were cleaned in xylene and mounted in DPX. After application of ANAE enzyme stain, they were examined under a light microscope. The proportions of ANAE $(+)$ and ANAE (-) lymphocytes were determined for each blood smear by counting 500 lymphocytes in a total of five areas (100 each one).

Statistical Analysis

The results obtained were analyzed using analysis of variance and Student's $t$-test. A value of $p<0.05$ and $p<0.01$ were considered significant.

\section{Results}

The levels of blood MDA and serum antioxidant levels are shown in Table 1. The MDA levels of Muscovy and Mallard, GSH levels of Pekin/Mallard and Muscovy and the vitamin $\mathrm{C}$ levels of Muscovy and Pekin and of Pekin and Mallard were found to be significantly different $(p<0.05)$.

Table 1. Blood MDA and serum non-enzymatic antioxidant levels for the three duck breeds

\begin{tabular}{|l|c|c|c|}
\hline & Mallard & Muscovy & Pekin \\
\hline MDA (nmol $\left.\cdot \mathrm{ml}^{-1}\right)$ & $0.8 \pm 0.2$ & $1.07 \pm 0.2^{\mathrm{a}}$ & $1.3 \pm 0.3^{\mathrm{b}}$ \\
GSH $\left(\mathrm{mg} \cdot 100 \mathrm{ml}^{-1}\right)$ & $77.4 \pm 6.8^{\mathrm{c}}$ & $66.89 \pm 5.8$ & $78.7 \pm 6.6^{\mathrm{c}}$ \\
Ceruloplasmin $\left(\mathrm{mg} \cdot 100 \mathrm{ml}^{-1}\right)$ & $23.9 \pm 2.8$ & $26.1 \pm 1.0$ & $24.1 \pm 2.8^{\mathrm{a}}$ \\
Vitamin C $\left(\mathrm{mg} \cdot 100 \mathrm{ml}^{-1}\right)$ & $0.50 \pm 0.2$ & $0.52 \pm 0.2^{\mathrm{d}}$ & $0.70 \pm 0.2^{\mathrm{a}}$ \\
\hline
\end{tabular}

Values are expressed as mean $\pm \mathrm{SD}, \mathrm{n}=8$ for each breed. MDA, malondialdehyde; GSH, reduced glutathione

a: $p<0.05$ compared with Mallard

b: $p<0.01$ compared with Mallard

c: $p<0.05$ compared with Muscovy

$\mathrm{d}: p<0.05$ compared with Pekin

In a light microscope examination, ANAE (+) lymphocytes had 1-4 distinct, red-brownish granules representing the reaction product by which they recognized T-lymphocytes. No reaction product was present in B-lymphocytes (Plate I, Fig. 1). The numbers of ANAE $(+)$ lymphocytes in the Mallards was higher than that in Pekin ducks or Muscovy ducks. The size of ANAE (+) lymphocytes was similar in all three breeds.

The results of ANAE staining are shown in Table 2. ANAE $(+)$ lymphocyte proportions were $57.9 \%, 54.8 \%$ and $55.1 \%$ in Mallard, Muscovy and Pekin ducks, respectively. Mallard was significantly different from the Muscovy duck $(p<0.05)$. The values were not significantly different between Muscovy and Pekin ducks $(p>0.05)$.

Table 2. ANAE staining in peripheral blood lymphocytes in ducks

\begin{tabular}{|l|l|l|}
\hline & \multicolumn{2}{|c|}{ Lymphocyte (\%) } \\
\hline Breed & ANAE $(+)$ & ANAE (-) \\
\hline Mallards & $57.9 \pm 5.8^{*}$ & $42.1 \pm 5.8$ \\
\hline Muscovy Ducks & $54.8 \pm 3.9$ & $45.2 \pm 3.9$ \\
\hline Pekin Ducks & $55.1 \pm 3.7$ & $44.9 \pm 3.7$ \\
\hline
\end{tabular}

Values are expressed as mean $\pm \mathrm{SD}, \mathrm{n}=8$ for each breed

$* p<0.05$ compared with Muscovy 


\section{Discussion}

One aim of this study was to investigate the blood levels of MDA, GSH, ceruloplasmin and vitamin $\mathrm{C}$ in different breeds of ducks. In the experiment, we observed that Pekin ducks had the highest levels of lipid peroxides (MDA), whereas Mallard ducks had the lowest level of ceruloplasmin and vitamin C (Table 1). All ceruloplasmin values showed some similarity and the values obtained were not significantly different $(p>0.05)$ between all three duck breeds.

Mezes et al. (1998) found MDA levels in blood plasma to be $1.52 \pm 0.75\left(\mathrm{mmol} \cdot\right.$ litre $\left.^{-1}\right)$ in ducks. In the present study, MDA values were determined to be $1.07 \pm 0.2,1.3 \pm 0.3$ and $0.8 \pm 0.2 \mathrm{nmol} \cdot \mathrm{ml}^{-1}$ for Moscovy, Pekin and Mallard ducks, respectively.

Previous studies have reported the levels of GSH to vary from species to species. Liver GSH levels found among the different classes are: mammals $\left(6-8 \mathrm{mmol} \cdot \mathrm{g}^{-1}\right)$, birds $(2.5-3.7$ $\left.\mathrm{mmol} \cdot \mathrm{g}^{-1}\right)$, amphibians $\left(0.9-2.2 \mathrm{mmol} \cdot \mathrm{g}^{-1}\right)$ and reptiles $\left(1-1.2 \mathrm{mmol} \cdot \mathrm{g}^{-1}\right)$ (Storey 1996). However, somewhat higher GSH concentrations in the liver of Canada goslings and Mallard ducklings of $3.7 \pm 0.3$ and $3.8 \pm 0.5 \mu \mathrm{mol} \cdot \mathrm{g}^{-1}$ respectively have been reported (Mateo and Hoffman 2001). In 16- and 30-week-old hybrid laying hens, GSH concentrations of $70.70 \pm 1.9$ and $57.26 \pm 0.8 \mathrm{mg} \cdot 100 \mathrm{ml}^{-1}$ have been found (Dede and Camas 2001). In another study, GSH levels were found to be $182.02 \pm 24.77,163.44 \pm 46.42$ and $39.23 \pm 5$ in chicken, duck and goose, respectively (Mezes et al. 1998). In the present study, the significant decrease in plasma concentrations of GSH in all duck breeds is in accordance with previous findings. Moreover, our data indicate that in the ducks examined, the blood antioxidant capacity is related to their phylogenetic group.

It has been found that vitamin C levels vary from species to species, with $0.48 \%, 1.30 \%$, $0.53 \%$, and $2.45 \%$ (Mert 1996) in humans, sheep, cows and chickens respectively and $0.52 \%$ in rats (Kanter et al. 2003). In the present study, the vitamin $\mathrm{C}$ level was found to be approximately $0.50-0.70 \mathrm{mg} \cdot 100 \mathrm{ml}^{-1}$ in all three duck breeds.

Ceruloplasmin levels have been reported to be $10.89 \mathrm{mg} \cdot 100 \mathrm{ml}^{-1}$ in dogs (Mengi and Serpek 1983), and $18.81 \mathrm{mg} \cdot 100 \mathrm{ml}^{-1}$ in rats (Kanter et al. 2003), whereas no records of duck levels could be found in the literature. The present work, ceruloplasmin levels were determined to be between 26.1 and $23.9 \mathrm{mg} \cdot 100 \mathrm{ml}^{-1}$, with the highest levels observed in Muscovy ducks.

ANAE staining results revealed that positive ANAE staining could be used as a marker for the T-lymphocytes of ducks. The staining patterns of ANAE $(+)$ was found to be similar to those reported by Asti et al. (1999) and Pruthi et al. (1987).

In the blood of humans (Knowles and Susan 1978; Müller et al. 1981), Van cats (Yörük et al. 1998) and Kangal dogs (Asti et al. 1993), red granular structures have been observed in the cytoplasm of T-lymphocytes. In the present study, 1-4 red granules were seen in most lymphocytes.

ANAE (+) lymphocyte proportions were $57.9 \%, 54.8 \%$ and $55.1 \%$ in Mallard, Muscovy and Pekin ducks, respectively. These proportions are close to the peripheral blood T-lymphocyte ratio of chickens (Maiti et al. 1990; Asti et al. 1999), but less than that of dogs (Asti et al. 1993), Van cats (Y örük et al. 1998), cows (Yang et al. 1979) and humans (Müller et al. 1979).

In this study, blood levels of lipid peroxidation and antioxidants were determined in Mallard, Muscovy and Pekin ducks. We found that peripheral blood T-lymphocytes could be identified specifically for the duck breeds by using the ANAE staining method.

\section{Peroxidace lipidů, koncentrace antioxidantů a alfanaftylacetát esterázové aktivity v lymfocytech periferní krve u kachny divoké, pižmovky velké a kachny pekinské}

Cílem studie bylo zjistit pomocí alfanaftylacetátesterázové (ANAE) metody koncentrace malondialdehydu (MDA), redukovaného glutathionu (GSH), ceruloplasminu, dále 
vitaminu $\mathrm{C}$ a procentuální podíl T-lymfocytů v periferní krvi u kachny divoké (Anas platyrhynchos), pižmovky velké (Cairina moschata) a kachny pekinské (Anas domestica). Vzorky krve byly odebrány osmi dospělým kachnám každého druhu. Sérové koncentrace u kachny divoké, pižmovky velké a kachny pekingské byly následující: MDA 0,8; 1,07 a 1,3 nmol. $\mathrm{ml}^{-1}$; GSH 77,4; 66,9 a 78,7 mg /100 ml; ceruloplasmin 23,9; 26,1 a 24,1 mg/100 $\mathrm{ml}$; a vitamin C 0,50; 0,52 a 0,70 mg/100 ml. Procentuální zastoupení ANAE (+) lymfocytů v krvi kachny divoké, pižmovky velké a kachny pekingské bylo 57,9\%, 54,8\% a 55,1\%. V této studii byla v krvi zjištěna hladina peroxidace lipidů a koncentrace neenzymatických antioxidantů u kachny divoké, pižmovky velké a kachny pekinské.

\section{References}

AKKUS I 1995: Free Radicals and Phsyopatologic Effects. Mimoza Press, Konya.

ASTI RN, KURTDEDE N, ERGÜN L 1993: Kangal köpeklerinin perifer kan T lenfositleri üzerinde isik ve elektron mikroskopik calismalar (Turkish). AÜ Vet Fak Derg 40: 563-576

ASTI RN, KURTDEDE N, ERGÜL L 1999: Light and electron microscopic studies on alpha naphthyl acetate esterase activity of peripheral blood T lymphocytes in chicken. Deut Tierarztl Woch 106: 397-399

BEUTLER E, DUBON O, KELLY BM 1963: Improved method for the determinetion of blood glutathione. J Lab Clin Med 61: 882-888

DEDE S, CAMAS H 2001: Yumurta tavuklarinda bazi biyokimyasal kan parametrelerinin (GSH, Hb ve Tf Tipleri ve $\mathrm{Mn}$ ) tayin edilmesi ve yumurta verimi üzerine etkilerinin arastirilmasi (Turkish). YYÜ Sag Bil Derg 7: 131138

ESTERBAUER H, CHEESEMAN KH 1990: Determination of aldehydic lipid peroxidation products: Malonaldehyde and 4-hydroxynonenal. Method Enzymol 186: 407 - 421

FUDENBERG H, STITES D, CALDWELL J, WELLS V 1978: Basic Clinical Immunolology Lange Medical Publication. California, pp. 78-95

HENSON DE, BLOCK G, LEVINE M 1991: Ascorbic Acid: biologic functions and relation to cancer. J Natl Cancer I 88: 547-552

HIGGY KE, BURNS GF, HAYHOE FGJ 1977: Discrimination of B, T and null lymphocytes by esterase cytochemistry. Scand J Hematol 18: 437-448

HUDSON VM 2001: Rethinking cystic fibrosis pathology: the critical role of abnormal reduced glutathione (GSH) transport caused by CFTR mutation. Free Radical Bio Med 30: 1440-1461

INOUE M, YAMAMOTO H, HIRARA H 1991: Ultrastructural cytochemical characterization of alpha-naphtyl acetate esterase in chicken monocytic cell lines. J Vet Med Sci 53: 415-418

JAIN SK, McVIE R, DUETT J, HERBST JJ 1989: Erythrocyte membrane lipid peroxidation and glycolylated hemoglobin in diabetes. Diabetes 38: 1539-1543

KAJIKAWA O, KOYAMA H, YOSHIKAWA T, TSUBAKI S, SAITO H 1983: Use of alpha-naphthyl acetate esterase staining to identify T lymphocytes in cattle. Am J Vet Res 44: 1549-52

KANTER M, MERAL I, DEDE S, GUNDUZ H, CEMEK M, OZBEK H, UYGAN I 2003: Effects of Nigella sativa L. Urtica dioica L. Lipid peroxidation, antioxidant enzyme systems and some liver enzymes in CCl4treated rats. J Vet Med A 50: 264-268

KELLY FJ 1999: Glutathione: in defence of the lung. Food Chem Toxicol 37: 963-966

KNOWLES DM, HALPER JP 1980: Human medullar and cortical tyhmocytes are distinguishable according to the presence or absence of cytochemically demonstrable acid alpha-naphtyl acetate esterase (ANAE) activity. J Immunol 125: 2823-2825

KNOWLES DM, SUSAN H 1978: Tissue localization of T lymphocytes by the histochemical demonstration of acid alpha naphthyl acetate esterase. Lab Invest 39: 70-76

KOH TS, PENG RK, CLASING KC 1996: Dietary copper level affects copper metabolism during lipopolysaccharide-induced immunological stress in chicks. Poultry Sci 75: 867-872

MAITI NK, SAINI SS, SHARMA SN 1990: Histochemical studies on chicken peripheral blood lymphocytes. Vet Res Commun 14: 207-210

MATEO R, HOFFMAN DJ 2001: Differences in oxidative stress between young Canada geese and mallards exposed to lead-contaminated sediment J Toxicol Env Health 64: 531-545

MENGI A, SERPEK B 1983: Normal ve hasta köpeklerin kan serumlarinda glutamik okzalasetik transaminaz (GOT), glutamik pirüviktransaminaz ve gama glutamil transpeptidaz ile serüloplazmin konsantrasyonu üzerine calismalar (Turkish). IÜ Vet Fak Derg 9: 21-27

MERT N 1996: Veteriner Clinical Biochemistry. Uludas Üniversitesi Vet. Fak., Bursa

MÉZES M, BARTA M, NAGY G 1998: Comparative investigation on the effect of T-2 mycotoxin on lipid peroxidation and antioxidant status in different poultry species. Res Vet Sci 66: 19-23

MIN KS, TERANO Y, ONOSAKA S, TANAKA K 1991: Induction of hepatic metallothionein by nonmetallic compounds associated with acute-phase response in inflammation. Toxicol Appl Pharm 111: 152-162 
MIYASAKA M, HERON I, DUDLER L, CAHILL RNP, FORNI L, KNAAK T, TRNAKA Z 1983: Studies on the differentiation of T lymphocytes in sheep. I. Recognition of a sheep T lymphocyte differentiation antigen by a monoclonal antibody T-80. Immunol 49: 545-552

MUELLER J, BRUN DEL RE G, BUERKI H, KELLER HU, HESS MW, COTTIER H 1975: Nonspecific acid esterase activity: a criterion for differentiation of $\mathrm{T}$ and B lymphocytes in mouse lymph nodes. Eur J Immunol 5: $270-274$

MÜLLER J, KELLER HU, HAGMANN JD, CORNIOLEY RJ, RUCHTI C, COTTIER H 1981: Nonspecific esterase in human lymphocytes. Int Arch Allergy Imm 64: 410-421

OMAYE ST, TURNBUL JD, SAVBERLICH HE 1979: Ascorbic acid analysis: II. Determimation after derivatisation with 2,2-dinitrophenylhidrizine. Selected metods for determination of ascorbic acid in animal cells tissues and fluids. In: McCorn D.B., and Wright L. (Ed.): Methods in Enzymology, vol. 62, Academic Press, New York, pp. 7-8

PIERTARINEN-RUNTTI P, LAKARI E, RAIVIO KO, KINNULA VL 2000: Expression of antioxidant enzymes in human inflammatory cells. Am J Physiol-Cell Ph 278: C118-C125

PRUTHI AK, GUPTA RKP, SADANA, JR 1987: Acid alpha naphthyl acetate esterase reacting lymphocytes in the peripheral blood of chicken challenged with Marek's disease after vaccination with three different vaccines. Res Vet Sci 43: 92-96

RAHMAN L, MACNEE W 1999: Lung glutathione and oxidative stress: implications in cigarette smoke-induced airway disease. Am J Physiol 277: L1067-L1088.

STOREY KB 1996: Metabolic adaptations supporting anoxia tolerance in reptiles: recent advances. Comp Biochem Phys B 113: 23-35

YANG TJ, JANTZEN PA, WILLIAMS LF 1979: Acid alpha-naphthyl acetate esterase: presence of activity in bovine and human T and B lymphocytes. Immunol 38: 85-93

YENSON M 1993: Clinical Biochemistry, Sixth edition, Beta Press Ltd., Istanbul

YÖRÜK M, ASTI RN, KURTDEDE N, AGAOGLU Z, ALTUNAY H 1998: Light and electron microscopic studies on alpha naphthyl acetate esterase activity of the peripheral blood T Lymphocytes in Van Cats. Anat Histol Embryol 27: 289-292

ZICCA A, LEPRINI A, CADONI A, FRANZI AT, FERRARINI M, GROSSI CE 1981: Ultrastructural localization of alpha-naphthyl acid esterase in human TM lymphocytes. Am J Pathol 105: 40-46 
Plate I

Karaca T. . et al.: Lipid Peroxidation ... pp. 33-38

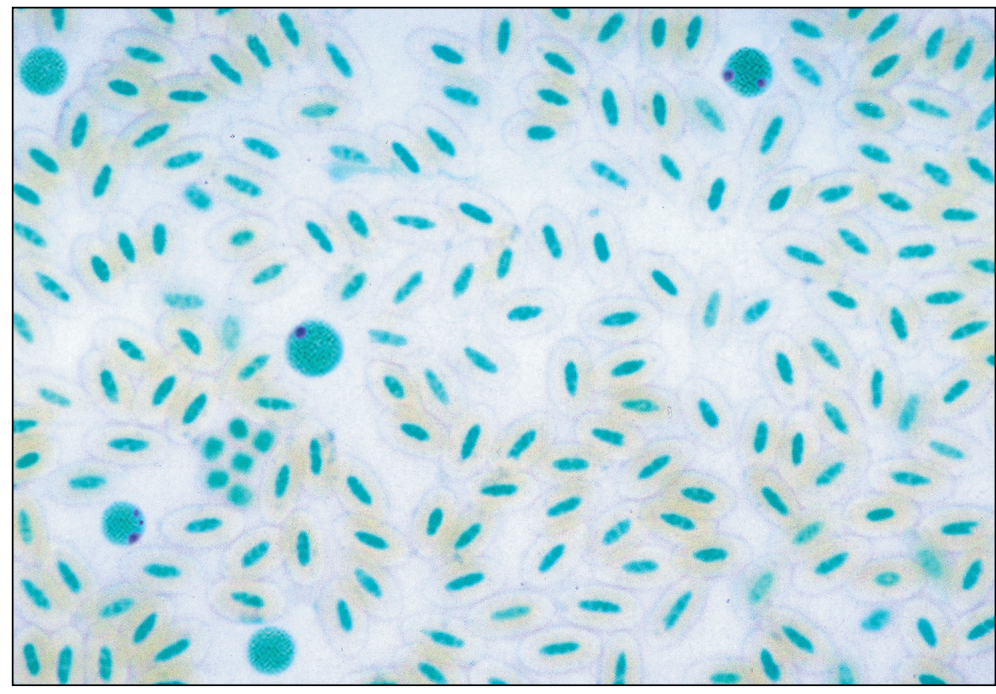

Fig.1. Alpha-napththyl acetate esterase (ANAE) staining in Pekin duck. ANAE-positive granules - T lymphocytes and ANAE-negative granules - B lymphocytes. ANAE, $\times 720$ 